\title{
Pseudozobellia thermophila gen. nov., sp. nov., a bacterium of the family Flavobacteriaceae, isolated from the green alga Ulva fenestrata
}

Correspondence
Olga I. Nedashkovskaya
olganedashkovska@yahoo.com

\author{
Olga I. Nedashkovskaya, ${ }^{1}$ Makoto Suzuki, ${ }^{2}$ Jung-Sook Lee, ${ }^{3}$ \\ Keun Chul Lee, ${ }^{3}$ Lyudmila S. Shevchenko ${ }^{1}$ and Valery V. Mikhailov ${ }^{1}$
${ }^{1}$ Pacific Institute of Bioorganic Chemistry of the Far-Eastern Branch of the Russian Academy of Sciences, Pr. 100 let Vladivostoku 159, 690022 Vladivostock, Russia Biotechnology, Yusong, Daejon 305-333, Republic of Korea \\ ${ }^{2}$ BioFrontier Laboratories, 3-6-6 Asahi-machi, Machida-shi, Tokyo 194-8533, Japan \\ ${ }^{3}$ Korean Collection for Type Cultures, Genetic Resources Center, Korea Institute of Bioscience and
}

Two novel aerobic, dark-orange-pigmented, Gram-negative bacterial strains, designated KMM $3531^{\top}$ and KMM 3953, were isolated from the green alga Ulva fenestrata. Analysis of the $16 \mathrm{~S}$ rRNA gene sequences showed that the strains represented a novel lineage within the family Flavobacteriaceae. The most closely related genera with validly published names were Costertonia, Flagellimonas, Kriegella, Maribacter, Muricauda and Zobellia, with 16S rRNA gene sequence similarities of 93.3-91.8\%. Cells of strains $\mathrm{KMM} 3531^{\top}$ and $\mathrm{KMM} 3953$ were rodshaped, motile by gliding and grew at temperatures up to $49^{\circ} \mathrm{C}$. They produced acid from carbohydrates and possessed oxidase, catalase, $\beta$-galactosidase and agarase activities. The

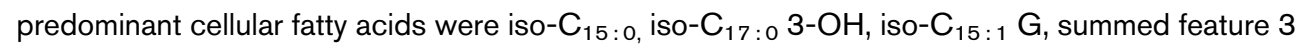
(comprising $\mathrm{C}_{16: 1} \omega 7 \mathrm{c}$ and/or iso- $\mathrm{C}_{15: 0} 2-\mathrm{OH}$ ), iso- $\mathrm{C}_{17: 1} \omega 9 \mathrm{c}$ and iso- $\mathrm{C}_{15: 0} 3-\mathrm{OH}$. The DNA $\mathrm{G}+\mathrm{C}$ content was $47-49 \mathrm{~mol} \%$. On the basis of phenotypic and genotypic characteristics, strains KMM $3531^{\top}$ and $\mathrm{KMM} 3953$ represent a novel genus and species, for which the name Pseudozobellia thermophila gen. nov., sp. nov. is proposed. The type strain is $\mathrm{KMM} 3531^{\top}$ $\left(=\right.$ DSM $19858^{\top}=$ JCM $11733^{\top}=$ KCTC $\left.22016^{\top}\right)$.
Members of the family Flavobacteriaceae (Bernardet et al., 2002) (www.bacterio.cict.fr/f/flavobacteriaceae.html) are commonly recovered from the surfaces of various algae inhabiting coastal waters. The green algae belonging to the genus Ulva harbour strains affiliated with bacterial taxa such as Cellulophaga, Flavobacterium, Gelidibacter and Salegentibacter (Lam \& Harder, 2007; Marshall et al., 2006; Nakanishi et al., 1996).

During a study of the taxonomic diversity of the bacterial epiphytes of Ulva fenestrata collected from Posiet Bay of the Sea of Japan (also known as the East Sea), two novel strains were isolated and their taxonomic positions were analysed using a polyphasic approach.

For strain isolation, $0.1 \mathrm{ml}$ algal tissue homogenate was plated on marine agar 2216 (Difco). After primary isolation and purification, the strains were cultivated at $28{ }^{\circ} \mathrm{C}$ on the same medium and stored at $-80{ }^{\circ} \mathrm{C}$ in marine broth 2216 (Difco) supplemented with $20 \%(\mathrm{v} / \mathrm{v})$ glycerol.

The GenBank/EMBL/DDBJ accession number for the 16S rRNA gene sequences of strains KMM $3531^{\top}$ and KMM 3953 are AB084261 and EU616814, respectively.
An almost-complete 16S rRNA gene sequence of isolate KMM $3531^{\mathrm{T}}$ was determined using PCR amplification and direct sequencing (Hiraishi, 1992). The conditions and reagents used for the PCR amplification and sequencing of the 16S rRNA gene were as described previously (Suzuki et al., 2001). The sequence was aligned on the secondarystructure model maintained by the European small subunit ribosomal RNA database (Van de Peer et al., 2000), using the profile-alignment program of CLUSTAL $\mathrm{W}$ (Thompson et al., 1994). Evolutionary distances were then computed with MEGA, version 3.1 (Kumar et al., 2004), using the twoparameter model (Kimura, 1980). Phylogenetic trees were constructed using the neighbour-joining (Saitou \& Nei, 1987) and maximum-parsimony (Fitch, 1971) methods. A maximum-likelihood analysis was also performed, using fastDNAml (Felsenstein, 1981). To evaluate the topology of the neighbour-joining phylogenetic tree, a bootstrap analysis based on 1000 replicates was performed using the SEQBOOT and CONSENSE programs in the PHYLIP 3.572 package (http://plaza.snu.ac.kr/ jchun/phydit/). Extraction of genomic DNA, PCR-mediated amplification of the $16 \mathrm{~S}$ rRNA gene of strain KMM 3953 and sequencing of purified 
PCR products were carried out as described by Rainey et al. (1996). The 16S rRNA gene sequence was aligned with published sequences retrieved from EMBL, using CLUSTAL_X (Thompson et al., 1997) and edited using BioEdit (Hall, 1999).

Analysis of the 16S rRNA gene sequences of strains KMM $3531^{\mathrm{T}}$ and KMM 3953 (1401 and $1403 \mathrm{nt}$, respectively) revealed that the strains belong to the family Flavobacteriaceae, forming a phylogenetic cluster with the genera Costertonia, Flagellimonas, Muricauda, Kriegella, Zobellia and Maribacter (Fig. 1). The 16S rRNA gene sequence similarity between strains $\mathrm{KMM} 3531^{\mathrm{T}}$ and KMM 3953 was $100 \%$. Kriegella aquimaris KMM $3665^{\mathrm{T}}$ was the nearest neighbour of the novel isolates, with a sequence similarity of $93.3 \%$. The $16 \mathrm{~S}$ rRNA gene sequence similarities between strain KMM $3531^{\mathrm{T}}$ and other close relatives were in the range 91.4-92.5\%. However, according to the topology of the neighbour-joining tree, Costertonia aggregata KOPRI $13342^{\mathrm{T}}$, Flagellimonas eckloniae $\mathrm{KCCM} 42307^{\mathrm{T}}$ and type strains of Muricauda species were more closely related to strain KMM $3531^{\mathrm{T}}$ than was $K$. aquimaris $\mathrm{KMM} 3665^{\mathrm{T}}$. The maximum-likelihood phylogenetic tree showed essentially the same topology (data not shown). Therefore, the two novel strains can be assigned to the family Flavobacteriaceae, in which they form a distinct lineage representing a separate genus, according to the criteria outlined by Stackebrandt \& Goebel (1994).

DNA was isolated by following the method of Marmur (1961) and the DNA G + C content was determined by means of the thermal denaturation method (Marmur \& Doty, 1962). The DNA G+C contents of strains KMM
$3531^{\mathrm{T}}$ and KMM 3953 were 49.0 and $47.9 \mathrm{~mol} \%$, respectively.

The DNA-DNA relatedness between the two strains was determined spectrophotometrically and initial renaturation rates were recorded as described by De Ley et al. (1970). The DNA-DNA relatedness between strains KMM $3531^{\mathrm{T}}$ and KMM 3953 was $93 \%$ : on the basis of the criteria of Wayne et al. (1987), this value confirms that the two strains represent the same species.

To compare the whole-cell fatty acid profiles of the novel strains and their nearest neighbours, strains $\mathrm{KMM} 3531^{\mathrm{T}}$, KMM 3953, Costertonia aggregata KOPRI $13342^{\mathrm{T}}$ and Flagellimonas eckloniae DOKDO $007^{\mathrm{T}}$ were grown under the same conditions [i.e. on marine agar 2216 (Difco) at $28{ }^{\circ} \mathrm{C}$ for $48 \mathrm{~h}$ ] and their fatty acid compositions were analysed according to the standard protocol of the Microbial Identification System (Microbial ID). The fatty analysis of K. aquimaris KMM $3665^{\mathrm{T}}$ and the type strains of species of the genus Zobellia had been performed using the same procedure, except that the bacteria had been grown for 24 h (Nedashkovskaya et al., 2004b, 2008).

The predominant cellular fatty acids (i.e. constituting $\geqslant 5 \%$ of total fatty acids) of strains $\mathrm{KMM} 3531^{\mathrm{T}}$ and KMM 3953 were the straight-chain and branched-chain saturated and unsaturated fatty acids iso- $\mathrm{C}_{15: 0}(30.8 \%)$, iso- $\mathrm{C}_{17: 0} 3-\mathrm{OH}(22.6 \%)$, iso- $\mathrm{C}_{15: 1} \mathrm{G}(14.8 \%)$, summed feature 3 (comprising $\mathrm{C}_{16: 1} \omega 7 \mathrm{c}$ and/or iso- $\mathrm{C}_{15: 0} 2-\mathrm{OH}$; $6.9 \%)$, iso- $\mathrm{C}_{17: 1} \omega 9 c(5.4 \%)$ and iso- $\mathrm{C}_{15: 0} 3-\mathrm{OH}(5.2 \%)$ (Table 1). Isoprenoid quinones were extracted and analysed using the method of Nakagawa \& Yamasato (1993). The major isoprenoid quinone in both strains was

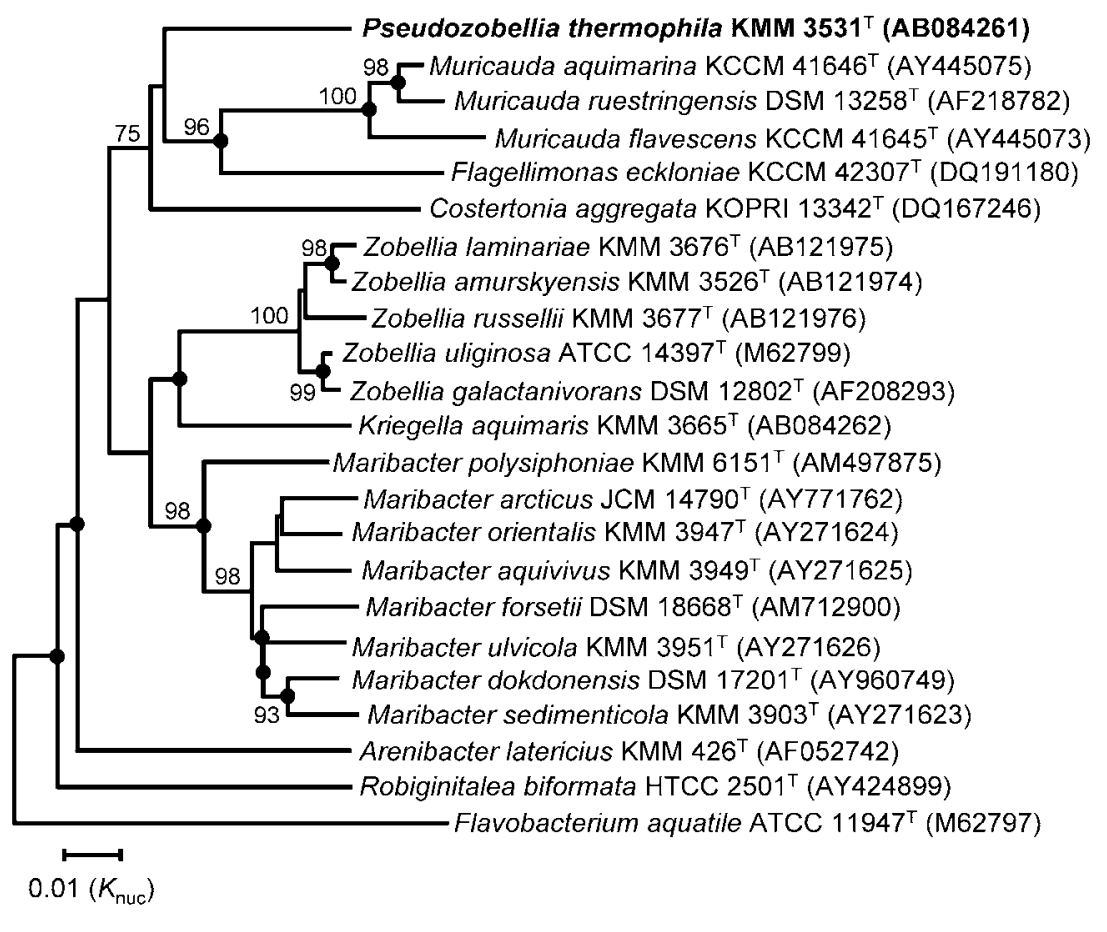

Fig. 1. Phylogenetic tree, based on $16 \mathrm{~S}$ rRNA gene sequences, showing the positions of strain KMM $3531^{\top}$ and type strains of recognized members of the family Flavobacteriaceae. The tree was generated using the neighbourjoining method (Saitou \& Nei, 1987). The 16S rRNA gene sequence of Flavobacterium aquatile ATCC $11947^{\top}$ (M62797) was used as an outgroup. Numbers at nodes indicate bootstrap percentages (based on 1000 replicates); only values $>50 \%$ are shown. Filled circles indicate nodes that were also recovered in the tree generated using the maximum-parsimony method (Fitch, 1971). Bar, genetic distance of $0.01 K_{\text {nuc }}$. 
Table 1. Whole-cell fatty acid compositions (\%) of strains $\mathrm{KMM} 3531^{\top}$ and $\mathrm{KMM} 3953$ (Pseudozobellia thermophila gen. nov., sp. nov.) and closely related members of the family Flavobacteriaceae

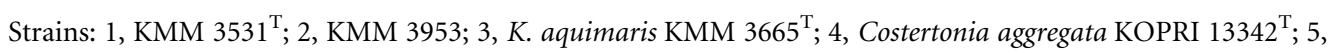
Flagellimonas eckloniae DOKDO $007^{\mathrm{T}}$; 6 , the type strains of the genus Zobellia (Z. amurskyensis KMM $3526^{\mathrm{T}}, Z$. galactanivorans Dsij ${ }^{\mathrm{T}}$, Z. laminariae $\mathrm{KMM} 3676^{\mathrm{T}}$, Z. russellii $\mathrm{KMM} 3677^{\mathrm{T}}$ and Z. uliginosa CIP $104808^{\mathrm{T}}$ ). Fatty acids constituting $<1 \%$ (mean) of the total in all taxa are not shown. Data are from Bae et al. (2007), Kwon et al. (2006), Nedashkovskaya et al. (2004b, 2008) and this study. All strains were analysed using the same procedure and grown under the same conditions, except that strain KMM $3665^{\mathrm{T}}$ and strains of the genus Zobellia were grown for $24 \mathrm{~h}$. Members of the genus Muricauda have not been included in the table because they were grown under different culture conditions. tr, Trace amount $(<1 \%)$; , not detected.

\begin{tabular}{|c|c|c|c|c|c|c|}
\hline Fatty acid & 1 & 2 & 3 & 4 & 5 & 6 \\
\hline \multicolumn{7}{|c|}{ Straight-chain fatty acids } \\
\hline $\mathrm{C}_{14: 0}$ & - & - & - & - & - & $0-1.0$ \\
\hline $\mathrm{C}_{15: 0}$ & 3.0 & 2.8 & 11.1 & 7.8 & 5.6 & $7.5-14.4$ \\
\hline $\mathrm{C}_{15: 1} \omega 6 c$ & $\operatorname{tr}$ & $\operatorname{tr}$ & 2.5 & $\operatorname{tr}$ & $\operatorname{tr}$ & $1.1-3.2$ \\
\hline $\mathrm{C}_{16: 0}$ & $\operatorname{tr}$ & $\operatorname{tr}$ & $\operatorname{tr}$ & 4.1 & 1.4 & $0.7-2.6$ \\
\hline $\mathrm{C}_{16: 0} 3-\mathrm{OH}$ & $\operatorname{tr}$ & $\operatorname{tr}$ & $\operatorname{tr}$ & 2.5 & 1.0 & $2.4-4.9$ \\
\hline $\mathrm{C}_{17: 1} \omega 6 c$ & - & - & - & - & - & $0-1.2$ \\
\hline $\mathrm{C}_{18: 0}$ & - & - & $\operatorname{tr}$ & - & 1.2 & - \\
\hline $\mathrm{C}_{18: 1} \omega 6 c$ & - & - & - & - & - & $0-1.1$ \\
\hline \multicolumn{7}{|l|}{ Branched fatty acids } \\
\hline anteiso- $\mathrm{C}_{15: 0}$ & $\operatorname{tr}$ & $\operatorname{tr}$ & $\operatorname{tr}$ & 1.2 & $\operatorname{tr}$ & $0-1.8$ \\
\hline iso- $\mathrm{C}_{15: 0}$ & 30.8 & 33.4 & 12.3 & 17.0 & 26.0 & $16.8-22.5$ \\
\hline iso- $\mathrm{C}_{15: 0} 3-\mathrm{OH}$ & 5.2 & 4.4 & 3.2 & 4.5 & 4.3 & $4.6-8.3$ \\
\hline iso- $\mathrm{C}_{15: 1} \mathrm{G}$ & 14.8 & 16.1 & 19.7 & 11.2 & 18.3 & $8.8-14.9$ \\
\hline iso- $\mathrm{C}_{16: 0} 3-\mathrm{OH}$ & $\operatorname{tr}$ & $\operatorname{tr}$ & $\operatorname{tr}$ & 1.8 & 1.4 & - \\
\hline iso- $\mathrm{C}_{17: 0}$ & - & - & - & 1.5 & - & - \\
\hline iso- $\mathrm{C}_{17: 0} 3-\mathrm{OH}$ & 22.6 & 20.7 & 12.8 & 22.7 & 25.1 & $15.1-25.9$ \\
\hline iso- $\mathrm{C}_{17: 1} \omega 9 c$ & 5.4 & 4.8 & 6.4 & 6.1 & 2.9 & $2.4-5.1$ \\
\hline \multicolumn{7}{|l|}{ Summed features* } \\
\hline 3 & 6.9 & 6.4 & 9.4 & 12.0 & 4.5 & 9.9-15.5 \\
\hline 4 & - & $\operatorname{tr}$ & 1.0 & - & - & - \\
\hline
\end{tabular}

${ }^{\star}$ Summed features are fatty acids that could not be separated using the MIDI system. Summed feature 3 consists of $\mathrm{C}_{16: 1} \omega 7 c$ and/or iso- $\mathrm{C}_{15: 0} 2-\mathrm{OH}$. Summed feature 4 consists of iso- $\mathrm{C}_{17: 1} \mathrm{I}$ and/or anteiso- $\mathrm{C}_{17: 1} \mathrm{~B}$.

MK-6, in line with all members of the family Flavobacteriaceae.

Physiological and biochemical features of strains KMM $3531^{\mathrm{T}}$ and KMM 3953 were tested as described by Nedashkovskaya et al. (2004a, b) and by using API 20E, API 20NE and API ZYM galleries (bioMérieux) according to the manufacturer's instructions (except that the incubation temperature was $28{ }^{\circ} \mathrm{C}$ ).

The novel isolates were heterotrophic, aerobic, dark-orangecoloured, Gram-negative organisms. Their main physiological and biochemical characteristics are given in Table 2 and in the genus and species descriptions. Cells were motile by gliding, grew at temperatures of up to $49{ }^{\circ} \mathrm{C}$ and decomposed agar, gelatin and DNA. In addition, strains KMM $3531^{\mathrm{T}}$ and KMM 3953 were characterized by the production of flexirubin-type pigments. The two strains differed from each other in several respects: in contrast to strain KMM $3531^{\mathrm{T}}$, strain KMM 3953 was able to produce acid from galactose, glucose, lactose, maltose, sucrose and cellobiose and was resistant to ampicillin. The differential properties of the two strains and related members of the family Flavobacteriaceae are shown in Table 2.

Therefore, the molecular data and phenotypic characteristics of strains $\mathrm{KMM} 3531^{\mathrm{T}}$ and $\mathrm{KMM} 3953$ strongly support their affiliation to the family Flavobacteriaceae of the phylum Bacteroidetes. However, the phylogenetic distances $(>5 \%)$ and differences in the fatty acid, physiological and biochemical data between the novel isolates and related bacteria justify the description of a new genus and novel species, for which the name Pseudozobellia thermophila gen. nov., sp. nov. is proposed.

\section{Description of Pseudozobellia gen. nov.}

Pseudozobellia (Pseu.do.zo.bel'li.a. Gr. adj. pseudes false; N.L. fem. n. Zobellia the name of a bacterial genus; N.L. fem. n. Pseudozobellia the false Zobellia). 
Table 2. Characteristics that differentiate strains $\mathrm{KMM} 3531^{\top}$ and $\mathrm{KMM} 3953$ (Pseudozobellia thermophila gen. nov., sp. nov.) from their closest relatives in the family Flavobacteriaceae

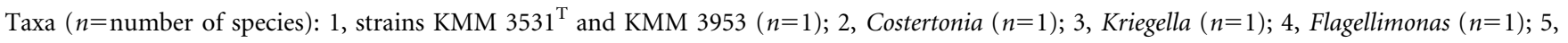
Muricauda ( $n=3) ; 6$, Zobellia ( $n=5)$. Data are from Bae et al. (2007), Barbeyron et al. (2001), Kwon et al. (2006), Nedashkovskaya et al. (2004b, 2008), Yoon et al. (2005) and this study. -, Negative; +, positive.

\begin{tabular}{|c|c|c|c|c|c|c|}
\hline Characteristic & 1 & 2 & 3 & 4 & 5 & 6 \\
\hline \multirow[t]{2}{*}{ Cell size $(\mu \mathrm{m})$} & $0.2-0.4 \times$ & $0.3-0.4 \times$ & $0.4-0.5 \times$ & $0.3-0.8 \times$ & $0.2-0.6 \times$ & $0.2-0.5 \times$ \\
\hline & $1.0-3.2$ & $0.5-4.2$ & $1.2-1.4$ & $1.2-2.3$ & $1.1-6.0$ & $1.2-8.0$ \\
\hline Gliding motility & + & - & + & - & - & + \\
\hline $\mathrm{Ca}^{2+}$ requirement for growth & - & + & - & + & - & - \\
\hline $\mathrm{K}^{+}$requirement for growth & - & + & - & - & - & - \\
\hline Nitrate reduction & - & + & - & - & - & + \\
\hline \multicolumn{7}{|l|}{ Degradation of: } \\
\hline Agar & + & - & - & - & - & + \\
\hline Gelatin & + & + & - & + & - & + \\
\hline Urea & - & + & - & - & - & - \\
\hline Salinity range $(\%)$ & $0.5-8$ & $1.5-12$ & $0.5-6$ & $1.9-5.4$ & $0.5-9$ & $0.5-10$ \\
\hline
\end{tabular}

Cells are strictly aerobic. Gram-negative. Cells do not form endospores. Non-diffusible pigments are produced. Chemo-organotrophic. Positive for cytochrome oxidase, catalase and alkaline phosphatase. The predominant cellular fatty acids are branched-chain saturated and unsaturated and straight-chain unsaturated fatty acids iso- $\mathrm{C}_{15: 0}$, iso- $\mathrm{C}_{17: 0} 3-\mathrm{OH}$, iso- $\mathrm{C}_{15: 1} \mathrm{G}$, summed feature 3 (comprising $\mathrm{C}_{16: 1} \omega 7 c$ and/or iso- $\mathrm{C}_{15: 0}$ 2- $\mathrm{OH}$ ), iso$\mathrm{C}_{17: 1} \omega 9 c$ and iso- $\mathrm{C}_{15: 0} 3-\mathrm{OH}$. The main respiratory quinone is $\mathrm{MK}-6$. The DNA $\mathrm{G}+\mathrm{C}$ content of the type species is $47-49 \mathrm{~mol} \%$. 16S rRNA gene sequence analysis indicates that the genus Pseudozobellia is a member of the family Flavobacteriaceae in the phylum Bacteroidetes. The type species is Pseudozobellia thermophila.

\section{Description of Pseudozobellia thermophila sp. nov.}

Pseudozobellia thermophila (ther.mo' phi.la. Gr. adj. thermos hot; Gr. adj. philos loving or having affinity for; N.L. fem. adj. thermophila heat-loving).

Exhibits the following properties in addition to those given in the genus description. Cells are regular rods, motile by gliding, and $0.2-0.4 \mu \mathrm{m}$ in width and 1.0-3.2 $\mu \mathrm{m}$ in length. On marine agar 2216, colonies are 2-3 $\mathrm{mm}$ in diameter, circular, shiny with entire edges, dark-orange-pigmented and sunken into the agar. Flexirubin-type pigments are produced. Growth occurs at $4-49{ }^{\circ} \mathrm{C}$ and with $0.5-8 \%$ $\mathrm{NaCl}$ (optimum, 4-5\% NaCl). Positive for $\beta$-galactosidase. Hydrolyses aesculin, agar, gelatin, alginate, DNA, tyrosine and Tweens 20, 40 and 80. Does not hydrolyse casein, starch, urea, cellulose (carboxymethylcellulose and filter paper) or chitin. Produces acid from L-arabinose, Lrhamnose and L-fucose but not from melibiose, raffinose,
L-sorbose, DL-xylose, $\mathrm{N}$-acetylglucosamine, citrate, malate, fumarate, adonitol, dulcitol, glycerol, inositol or mannitol. Acid production from D-galactose, D-glucose, D-lactose, maltose, sucrose and cellobiose is strain-dependent. DGlucose, D-lactose, D-mannose, sucrose and mannitol are utilized but inositol, sorbitol, malonate and citrate are not. With the API ZYM gallery, esterase (C4), esterase lipase (C8), leucine arylamidase, cystine arylamidase, valine arylamidase, trypsin, $\alpha$-chymotrypsin, acid and alkaline phosphatases, naphthol-AS-BI-phosphohydrolase, $\alpha$ - and $\beta$-galactosidases, $\alpha$ - and $\beta$-glucosidases, $N$-acetyl- $\beta$-glucosaminidase, $\alpha$-mannosidase and $\alpha$-fucosidase activities are present, but lipase (C14) and $\beta$-glucuronidase activities are absent. Nitrate is not reduced. $\mathrm{H}_{2} \mathrm{~S}$, indole and acetoin (Voges-Proskauer reaction) are not produced. Susceptible to carbenicillin $(100 \mu \mathrm{g})$, chloramphenicol $(30 \mu \mathrm{g})$, lincomycin $(15 \mu \mathrm{g})$, oleandomycin $(15 \mu \mathrm{g})$ and erythromycin $(15 \mu \mathrm{g})$, but resistant to benzyl penicillin (10 U), gentamicin $(10 \mu \mathrm{g})$, doxycycline $(10 \mu \mathrm{g})$, kanamycin $(30 \mu \mathrm{g})$, neomycin $(30 \mu \mathrm{g})$, polymyxin $(300 \mathrm{U})$, streptomycin $(30 \mu \mathrm{g})$ and tetracycline $(30 \mu \mathrm{g})$. Susceptibility to ampicillin $(10 \mu \mathrm{g})$ is strain-dependent. The DNA G + C content of the type strain is $49.0 \mathrm{~mol} \%$.

The type strain, KMM $3531^{\mathrm{T}}$ (=DSM $19858^{\mathrm{T}}=\mathrm{JCM}$ $11733^{\mathrm{T}}=$ KCTC $22016^{\mathrm{T}}$ ), was isolated from the green alga Ulva fenestrata in Posiet Bay, Sea of Japan (also known as the East Sea). A reference strain, KMM 3953 (=KCTC 22017), was isolated from the same source.

\section{Acknowledgements}

This research was supported by grants from the Russian Foundation for Basic Research (no. 08-04-00099), the Presidium of the Far- 
Eastern Branch of the Russian Academy of Sciences (no. 06-III-A-06183), the Presidium of the Russian Academy of Sciences ('Molecular and Cell Biology') and by a grant from the KRIBB Research Initiative Program.

\section{References}

Bae, S. S., Kwon, K. K., Yang, S. H., Lee, H. S., Kim, S. J. \& Lee, J. H. (2007). Flagellimonas eckloniae gen. nov., sp. nov., a mesophilic marine bacterium of the family Flavobacteriaceae, isolated from the rhizosphere of Ecklonia kurome. Int J Syst Evol Microbiol 57, 1050-1054.

Barbeyron, T., L'Haridon, S., Corre, E., Kloareg, B. \& Potin, P. (2001). Zobellia galactanovorans gen. nov., sp. nov., a marine species of Flavobacteriaceae isolated from red alga, and classification of [Cytophaga] uliginosa (ZoBell and Upham 1944) Reichenbach 1989 as Zobellia uliginosa gen. nov., comb. nov. Int J Syst Evol Microbiol 51, 985-997.

Bernardet, J.-F., Nakagawa, Y. \& Holmes, B. (2002). Proposed minimal standards for describing new taxa of the family Flavobacteriaceae and emended description of the family. Int J Syst Evol Microbiol 52, 1049-1070.

De Ley, J., Cattoir, H. \& Reynaerts, A. (1970). The quantitative measurement of DNA hybridization from renaturation rates. Eur $J$ Biochem 12, 133-142.

Felsenstein, J. (1981). Evolutionary trees from DNA sequences: a maximum likelihood approach. J Mol Evol 17, 368-376.

Fitch, W. M. (1971). Toward defining the course of evolution: minimum change for a specific tree topology. Syst Zool 20, 406-416.

Hall, T. A. (1999). BioEdit: a user-friendly biological sequence alignment editor and analysis program for Windows 95/98/NT. Nucleic Acids Symp Ser 41, 95-98.

Hiraishi, A. (1992). Direct automated sequencing of $16 \mathrm{~S}$ rDNA amplified by polymerase chain reaction from bacterial cultures without DNA purification. Lett Appl Microbiol 15, 210-213.

Kimura, M. (1980). A simple method for estimating evolutionary rates of base substitutions through comparative studies of nucleotide sequences. J Mol Evol 16, 111-120.

Kumar, S., Tamura, K. \& Nei, M. (2004). MEGA3: integrated software for molecular evolutionary genetics analysis and sequence alignment. Brief Bioinform 5, 150-163.

Kwon, K. K., Lee, Y. K. \& Lee, H. K. (2006). Costertonia aggregata gen. nov., sp. nov., a mesophilic marine bacterium of the family Flavobacteriaceae, isolated from a mature biofilm. Int J Syst Evol Microbiol 56, 1349-1353.

Lam, C. \& Harder, T. (2007). Marine macroalgae affect abundance and community richness of bacterioplankton in close proximity. J Phycol 43, 874-881.

Marmur, J. (1961). A procedure for the isolation of deoxyribonucleic acid from microorganisms. J Mol Biol 3, 208-218.

Marmur, J. \& Doty, P. (1962). Determination of the base composition of deoxyribonucleic acid from its thermal denaturation temperature. $J$ Mol Biol 5, 109-118.

Marshall, K., Joint, I., Callow, M. \& Callow, J. (2006). Effect of marine bacterial isolates on the growth and morphology of axenic plantlets of the green alga Ulva linza. Microb Ecol 52, 302-310.

Nakagawa, Y. \& Yamasato, K. (1993). Phylogenetic diversity of the genus Cytophaga revealed by $16 \mathrm{~S}$ rRNA sequencing and menaquinone analysis. J Gen Microbiol 139, 1155-1161.
Nakanishi, K., Nishijima, M., Nishimura, M., Kuwano, K. \& Saga, N. (1996). Bacteria that induce morphogenesis in Ulva pertusa (Chlorophyta) grown under axenic conditions. J Phycol 32, 479-482.

Nedashkovskaya, O. I., Kim, S. B., Han, S. K., Lysenko, A. M., Rohde, M., Rhee, M.-S., Frolova, G. M., Falsen, E., Mikhailov, V. V. \& Bae, K. S. (2004a). Maribacter gen. nov., a new member of the family Flavobacteriaceae, isolated from marine habitats, containing the species Maribacter sedimenticola sp. nov., Maribacter aquivivus sp. nov., Maribacter orientalis sp. nov. and Maribacter ulvicola sp. nov. Int J Syst Evol Microbiol 54, 1017-1023.

Nedashkovskaya, O. I., Suzuki, M., Vancanneyt, M., Cleenwerck, I., Lysenko, A. M., Mikhailov, V. V. \& Swings, J. (2004b). Zobellia amurskyensis sp. nov., Zobellia laminariae sp. nov. and Zobellia russellii sp. nov., novel marine bacteria of the family Flavobacteriaceae. Int J Syst Evol Microbiol 54, 1643-1648.

Nedashkovskaya, O. I., Suzuki, M., Kim, S. B. \& Mikhailov, V. V. (2008). Kriegella aquimaris gen. nov., sp. nov., isolated from marine environments. Int J Syst Evol Microbiol 58, 2624-2628.

Rainey, F. A., Ward-Rainey, N., Kroppenstedt, R. M. \& Stackebrandt, E. (1996). The genus Nocardiopsis represents a phylogenetically coherent taxon and a distinct actinomycete lineage: proposal of Nocardiopsaceae fam. nov. Int J Syst Bacteriol 46, 1088-1092.

Saitou, N. \& Nei, M. (1987). The neighbor-joining method: a new method for reconstructing phylogenetic trees. Mol Biol Evol 4, 406425.

Stackebrandt, E. \& Goebel, B. M. (1994). Taxonomic note: a place for DNA-DNA reassociation and $16 \mathrm{~S}$ rRNA sequence analysis in the present species definition in bacteriology. Int J Syst Bacteriol 44, 846849.

Suzuki, M., Nakagawa, Y., Harayama, S. \& Yamamoto, S. (2001). Phylogenetic analysis and taxonomic study of marine Cytophaga-like bacteria: proposal for Tenacibaculum gen. nov. with Tenacibaculum maritimum comb. nov., and Tenacibaculum ovolyticum comb. nov., and description of Tenacibaculum mesophilum sp. nov. and Tenacibaculum amylolyticum sp. nov. Int J Syst Evol Microbiol 51, $1639-1652$.

Thompson, J. D., Higgins, D. G. \& Gibson, T. J. (1994). CLUSTAL W: improving the sensitivity of progressive multiple sequence alignment through sequence weighting, position-specific gap penalties and weight matrix choice. Nucleic Acids Res 22, 4673-4680.

Thompson, J. D., Gibson, T. J., Plewniak, F., Jeanmougin, F. \& Higgins, D. G. (1997). The CLUSTAL_X windows interface: flexible strategies for multiple sequence alignment aided by quality analysis tools. Nucleic Acids Res 25, 4876-4882.

Van de Peer, Y., De Rijk, P., Wuyts, J., Winkelmans, T. \& De Wachter, R. (2000). The European small subunit ribosomal RNA database. Nucleic Acids Res 28, 175-176.

Wayne, L. G., Brenner, D. J., Colwell, R. R., Grimont, P. A. D., Kandler, O., Krichevsky, M. I., Moore, L. H., Moore, W. E. C., Murray, R. G. E. \& other authors (1987). International Committee on Systematic Bacteriology. Report of the ad hoc committee on reconciliation of approaches to bacterial systematics. Int $J$ Syst Bacteriol 37, 463-464.

Yoon, J. H., Lee, M. H., Oh, T. K. \& Park, Y. H. (2005). Muricauda flavescens sp. nov. and Muricauda aquimarina sp. nov., isolated from a salt lake near Hwajinpo Beach of the East Sea in Korea, and emended description of the genus Muricauda. Int J Syst Evol Microbiol 55, 1015-1019. 